\title{
The endocannabinoid system and spermatogenesis
}

\author{
Paola Grimaldi *, Daniele Di Giacomo and Raffaele Geremia \\ Section of Anatomy, Department of Biomedicine and Prevention, University of Rome "Tor Vergata," Rome, Italy
}

\section{Edited by:}

Riccardo Pierantoni, Seconda

Università di Napoli, Italy

\section{Reviewed by:}

Gilda Cobellis, Second University of Naples, Italy

Silvia Fasano, Second University of Naples, Italy

\section{*Correspondence:}

Paola Grimaldi, Section of Anatomy,

Department of Biomedicine and

Prevention, University of Rome "Tor

Vergata," Via Montpellier 1, Rome

00133, Italy

e-mail:p.grimaldi@med.uniroma2.it

\begin{abstract}
Spermatogenesis is a complex process in which male germ cells undergo a mitotic phase followed by meiosis and by a morphogenetic process to form mature spermatozoa. Spermatogenesis is under the control of gonadotropins, steroid hormones and it is modulated by a complex network of autocrine and paracrine factors. These modulators ensure the correct progression of germ cell differentiation to form mature spermatozoa. Recently, it has been pointed out the relevance of endocannabinoids as critical modulators of male reproduction. Endocannabinoids are natural lipids able to bind to cannabinoid receptors and whose levels are regulated by specific biosynthetic and degradative enzymes. Together with their receptors and metabolic enzymes, they form the "endocannabinoid system" (ECS). In male reproductive tracts, they affect Sertoli cell activities, Leydig cell proliferation, germ cell differentiation, sperm motility, capacitation, and acrosome reaction. The ECS interferes with the pituitary-gonadal axis, and an intricate crosstalk between ECS and steroid hormones has been highlighted. This mini-review will focus on the involvement of the ECS in the control of spermatogenesis and on the interaction between ECS and steroid hormones.
\end{abstract}

Keywords: male germ cells, spermatogenesis, endocannabinoid system, sex hormones, cannabinoid

\section{INTRODUCTION}

Infertility affects $10-15 \%$ of couples, and it has been estimated that a male factor is responsible in approximately half of these cases. Male infertility is diagnosed with the analysis of several semen parameters, such as the number of total sperm, sperm motility, and percentage of sperm cells with a normal morphology. It is known that marijuana, the commonest recreational drug of abuse, has adverse effects on male reproductive physiology. Its use is associated with impotence, decreased testosterone plasma level, impairment of spermatogenesis, production of spermatozoa with abnormal morphology, reduction of sperm motility and viability and, more recently, with the occurrence of non-seminoma germ cell tumors (1). The identification of endogenous cannabinoids (ECBs) that mimic some effects of delta-9-THC, the active principle of Cannabis sativa, has opened new studies on the biological role of ECBs in male reproduction. In this mini-review we focused on the relevance of endocannabinoids and "endocannabinoid system" (ECS) in spermatogenesis and sperm functions, and on the interplay between ECS and sex hormone.

\section{SPERMATOGENESIS}

Spermatogenesis is a complex differentiative process starting from spermatogonial stem cells (SSCs), known as A-single $\left(\mathrm{A}_{s}\right)$. The $\mathrm{A}_{s}$ cells, similarly to other stem cells, have the capability to self-renew, producing daughter $A_{s}$ cells, and to progress into "undifferentiated spermatogonia" known as A-paired $\left(\mathrm{A}_{\mathrm{pr}}\right)$, and A-aligned $\left(\mathrm{A}_{\mathrm{al}}\right)$ that represent committed cells. The $A_{a l}$ spermatogonia then differentiate into A1-4, intermediate (In) and B spermatogonia which undergo meiosis as pre-leptotene spermatocytes (2). Spermatocytes pass sequentially through leptotene, zygotene, pachytene, and diplotene phases of prophase I, and then quickly undergo two M-phase divisions, yielding haploid spermatids, that became spermatozoa through the morphogenetic process called spermiogenesis. Sperm released from the seminiferous epithelium into the tubule lumen are still immature and are not able to fertilize an egg. Sperm maturation occur in the epididymis. During spermatogenesis, germ cells, at each stage of differentiation, are in close contact with Sertoli cells which provide physical and metabolic support for their proliferation, meiosis, and successful progression into spermatozoa. Sertoli cells proliferate quickly during perinatal period and they switch to a mature, non-proliferative state, around the onset of puberty. Since only a limited number of germ cells can be supported by each Sertoli cell (3), in adult testis, the number of Sertoli cells will be a critical factor with obvious consequences on fertility.

Spermatogenesis continues throughout life and it is regulated by a complex assortment of hormones as well as numerous locally produced factors that include growth factors, cytokines, and chemokines, that act through autocrine and paracrine pathways. Sertoli cell-secreted growth factors are known to have direct effects mainly on spermatogonia: Gdnf acts on self-renewal of SSCs and inhibits their differentiation (4), Bmp4 has both a proliferative and differentiative effect on these cells (5), and Kit Ligand $(\mathrm{KL})$, acts on the kit tyrosine-kinase receptor expressed by differentiating type A spermatogonia (6) stimulating their progression into the mitotic cell cycle and reducing apoptosis (7). The major hormonal control system of spermatogenesis is the hypothalamicpituitary-gonadal axis, based essentially on the release of two gonadotropins, luteinizing hormone ( $\mathrm{LH})$ and follicle stimulating hormone (FSH), under the stimulation of hypothalamic GnRHs. Leydig and Sertoli cells, the somatic cells of the testis, are primary responders to circulating gonadotropin hormones and their failure to respond appropriately, results in male infertility (8). LH stimulates Leydig cells to synthesize testosterone (T) and FSH acts 
on Sertoli cells stimulating their proliferation and expression of several trophic factors essential for spermatogenesis.

\section{THE ENDOCANNABINOID SYSTEM}

Endocannabinoids are lipid-signal molecules that are endogenous ligands for cannabinoid receptors, and together with enzymes responsible for their synthesis and degradation, they form the "ECS" (9). ECS is conserved from invertebrate to mammals and it assumes important role in physiological and pathological processes. The two best characterized endocannabinoids are $N$-arachidonoyl ethanolamine (AEA, anandamide) and 2 arachidonoyl glycerol (2-AG).

Endogenous cannabinoids bind to and activate their target receptors, causing several biological effects on different tissues. The main cannabinoid receptor targets type- $1\left(\mathrm{CB}_{1}\right)$ and type$2\left(\mathrm{CB}_{2}\right)$ are seven trans-membrane $\mathrm{G}$ protein-coupled receptors (10). $\mathrm{CB}_{1}$ is widely expressed in the nervous system mainly at the terminal ends of central and peripheral neurons, but it is also expressed in ovary, uterus, testis, vas deferens, and urinary bladder. $\mathrm{CB}_{2}$ is mainly expressed in the cells of the immune system but it is also found in brainstem (11). ECBs are released from membrane phospholipid precursors by specific phospholipases, that are activated "on demand." AEA synthesis is catalyzed by an $N$-acylphosphatidylethanolamine-specific phospholipase D (NAPE-PLD) (12). Similarly, the formation of 2-AG involves a rapid hydrolysis of inositol phospholipids by a specific phospholipase $\mathrm{C}$ (PLC) to generate diacylglycerol (DAG), which is then converted into 2-AG by an sn-1-DAG lipase (DAGL) (13). As lipid molecules, ECBs diffuse passively through the membrane, but the presence of a membrane transporter, EMT, that acts by a facilitated diffusion mechanism, has been hypothesized $(14,15)$. More recently an anandamide transporter named FLAT, which facilitates its translocation into cells has been identified in neural cells (16). The biological effects of ECBs depend on their lifespan in the extracellular space, which is limited by a re-uptake by cells. Once inside the cells ECBs are hydrolyzed by two specific enzymes: the fatty acid amide hydrolase (FAAH) cleaves AEA into arachidonic acid and ethanolamine, and the monoacylglycerol lipase (MAGL) (17) transforms the 2-AG into arachidonic acid and glycerol (18).

AEA, but not 2-AG, behaves also as an endovanilloid binding to the type-1 vanilloid receptor (transient receptor potential vanilloid 1, TRPV1) at an intracellular site (19). TRPV1 is a six transmembrane spanning non-selective cation channel, whose expression is found mainly in specialized sensory neurons that detect painful stimuli (20). However it is now established that TRPV1 is expressed also in non-neuronal cells, such as keratinocytes and epithelial and endothelial cells, where it could play a wide variety of physiological functions.

\section{THE ENDOCANNABINOID SYSTEM AND SPERMATOGENESIS ECS AND GERM CELLS}

Following the discovery of ECS, many studies about its expression and function in male reproductive system have been carried out (21). The presence of components of ECS has been demonstrated in the testis, in the reproductive fluids and tracts, in different organisms from invertebrates to mammals. All the components of the ECS have been identified in mammalian germ cells, from spermatogonia to spermatozoa.

First evidence of an effect of cannabinoid in male reproduction comes from a study in sea urchin in which it was demonstrated that exogenous cannabinoid THC directly reduced the fertilizing capacity of sperm (22) through the inhibition of the acrosome reaction (23). Next, endogenous cannabinoid AEA was shown to induce the same effects of THC on sea urchin sperm (24).

Endocannabinoids have been identified in human seminal plasma (25), in the amphibian cloacal fluid (26) and in mouse epididymis (27) indicating a role in the control of sperm functions. Most of the in vitro studies reported an adverse effect of AEA on sperm function with inhibition of motility, capacitation and acrosome reaction, and indicated a pivotal role of $\mathrm{CB}_{1}$ receptor in mediating AEA effects. In humans, AEA inhibits sperm motility by decreasing mitochondrial activity and this effect was blocked by the $\mathrm{CB}_{1}$ receptor antagonist SR141716 (28). In boar (Sus scropha), a stable AEA analog, methanandamide, reduces sperm capacitation and inhibits acrosome reaction (29). Also in frog Rana esculenta AEA has been shown to inhibit sperm motility through $\mathrm{CB}_{1}$ receptor (26).

It has been described a role of $\mathrm{CB}_{1}$ in spermiogenesis, when elongated spermatids are remodeled to form mature spermatozoa with a change in the chromatin structure. Indeed, genetic inactivation of $\mathrm{CB}_{1}$ causes an inefficient histone displacement, poor chromatin condensation, and DNA damage in sperm (30), indicating a role of ECS in spermatid differentiation.

Further interesting findings supporting a role of $A E A$ and $C_{1}$ receptor on sperm function arise from the gene knockout animal models. In the absence of $\mathrm{CB}_{1}$ signaling, sperm acquire motility precociously and the percentage of motile spermatozoa recovered from the caput of epididymis was higher with respect to wild-type mice, suggesting a physiological inhibitory regulation of endocannabinoids on sperm motility in the epididymis (31). Genetic loss of FAAH results in increased levels of AEA in the reproductive system and impairment of sperm fertilizing ability (32). These results lead to hypothesize that an "adequate tone" of AEA and the expression of $\mathrm{CB}_{1}$ receptor are critical in the formation of morphologically and functionally normal sperm. In support of this observation, it has been recently reported that, in rats, in vivo administration of HU210, a synthetic analog of THC and a potent agonist of $\mathrm{CB}$ receptors, causes a marked impairment of spermatogenesis with reduction in total sperm count and motility, and a deregulation of the ECS, confirming the in vitro observations and indicating that the use of exo-cannabinoids may influence adversely male fertility (33).

Another molecular target of AEA is the vanilloid receptor TRPV1 (34), expressed in sperm cells of mouse (35), boar (29), bull (36), and humans (37). Activation of TRPV1 receptor by AEA, seems to play a role in the stabilization of the plasma membranes in capacitated boar sperm, preventing spontaneous acrosome reaction (29). Therefore, AEA can bring different signals in sperm cells, depending on the target receptor $\left(\mathrm{CB}_{1}\right.$ or TRPV1) that is activated.

Besides AEA, also the endocannabinoid 2-AG has been reported to affect male reproduction. Using mouse male germ cell populations at different stage of differentiation we highlighted a pivotal role of 2-AG and $\mathrm{CB}_{2}$ receptor in mouse spermatogenesis (35). 
We demonstrated that mammalian male germ cells, from mitotic to haploid stage, have a complete ECS which is modulated during spermatogenesis. Spermatogonia possess higher level of 2-AG that decreases in spermatocytes and drastically drops in spermatids. This correlates to higher level of biosynthetic (DAGL) and lower level of degrading enzymes (MAGL) in spermatogonia with respect to spermatocytes and spermatids. On the contrary, AEA levels remain unchanged during spermatogenesis and probably are crucial to maintain, locally, an appropriate "anandamide tone" for a correct progression of spermatogenesis as seen for normal development of mouse embryos (38). Interestingly, activation of $\mathrm{CB}_{2}$ receptor in spermatogonia promotes their progression into meiosis as revealed by an increased number of cells positive for the meiotic marker SCP3 and by the expression of premeiotic and early meiotic genes. Thus, during spermatogenesis an autocrine endocannabinoid regulation of mitotic germ cell differentiation might occur as proposed in Figure 1.

Endocannabinoid 2-AG has been also found to play a role in regulating the ability of spermatozoa to become motile during their transit in the epididymis. 2-AG levels are high in mouse spermatozoa isolated from the caput of the epididymis, where they do not move regularly, and decrease dramatically in spermatozoa isolated from the cauda, where they acquire vigorous motility, suggesting that, along the epididymis, the decrease of 2-AG levels from caput to cauda promotes start-up of spermatozoa (27). Finally mouse sperm capacitation has been found to be linked to an enhancement of the endogenous tone of both AEA and 2-AG (39), underlying the important role of ECS in regulating important step of spermatogenesis and sperm functions.

With the aim to investigate, in humans, a possible relationship between male reproductive dysfunction and deregulation of the ECS, recent studies have shown a marked reduction of AEA and 2-AG content in the seminal plasma of infertile patients. This reduction in sperm from infertile versus fertile men can be determined by either an increased ratio of degradation/biosynthesis, or by lower levels of $\mathrm{CB}_{1}$ mRNA expression (40,41), indicating that the ECBs signaling is involved in the preservation of normal human sperm function.

\section{ECS AND TESTICULAR SOMATIC CELLS}

Endocannabinoid system components are expressed also in somatic cells of mammalian testis. Sertoli cells possess the biochemical machinery to synthesize, transport, degrade, and bind both AEA (42) and 2-AG (43). Mouse Sertoli cells express a functional $\mathrm{CB}_{2}$ receptor, an $\mathrm{AEA}$ membrane transporter and the AEA-degrading enzyme FAAH (42). AEA has been shown to have a pro-apoptotic effect on Sertoli cells, inducing DNA fragmentation. Lower level of AEA correlates with higher level of FAAH protein and with a decrease in Sertoli cell apoptosis, suggesting a protective and pro-survival role of FAAH in Sertoli cells. More interestingly, FAAH activity and expression is hormonally up-regulated in Sertoli cells by FSH and estrogen $(43,44)$.

Rat Leydig cells express $\mathrm{CB}_{1}$ which is modulated during development and it negatively correlates to cell division. Immature Leydig cells in mitosis were negative for $\mathrm{CB}_{1}$, while immature non-mitotic Leydig cells were positive, indicating a negative effect of $\mathrm{CB}_{1}$ on Leydig cell proliferation and suggesting that their differentiation may depend on the ECS (45).

\section{THE ENDOCANNABINOID SYSTEM AND SEX HORMONE}

As described above, the ECS is widely distributed in testicular cells and it is an important regulator of spermatogenesis and sperm functions. Recently, many evidence indicate the existence of interplay between ECS and sex hormones, testosterone and estrogen, thus stressing the relevant role of ECS in regulating male reproduction. Testosterone is produced by Leydig cells under the stimulation of LH and it is essential for the occurrence of events like blood-testis-barrier formation, germ cells progression beyond meiosis, mature sperm release. Sertoli cells are the major cellular target for the testosterone signaling and the absence of testosterone or of the androgen receptor, results in the failure of spermatogenesis and infertility. Several studies on human males smoking cannabis, reported a decrease in plasma levels of testosterone, FSH, and $\mathrm{LH}$ and this effect was also evident in animal studies after acute and chronic administration of THC $(46,47)$. Decreased levels of testosterone correlate to an inhibitory effect of cannabinoids on male sexual behavior (48). Moreover in vitro studies on Leydig cells showed a decrease in testosterone secretion induced by THC (49). Similarly endogenous cannabinoid AEA suppresses LH and testosterone levels in wild-type, but not in $\mathrm{CB}_{1}$ knockout mice (50), providing evidence that the ECS acts to suppress testosterone levels.

It is now well documented that, beside testosterone, also estrogens are important modulator of male reproduction (51). The mitosis

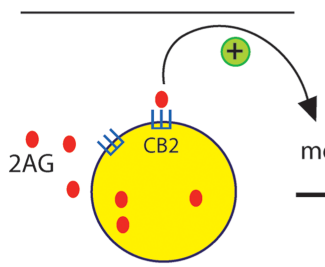

spermatogonium B

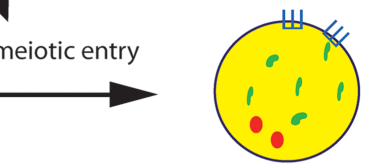

leptotene spermatocyte meiotic prophase I

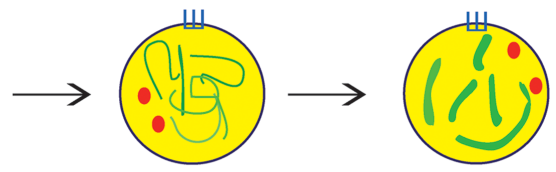

zygotene spermatocyte pachytene spermatocyte
FIGURE 1 | Effect of $\mathrm{CB}_{\mathbf{2}}$ activation on the early steps of spermatogenic differentiation. Mitotic male germ cells express $C_{2}$ receptor and high level of 2-AG. Activation of $\mathrm{CB}_{2}$ receptor by $2-A G$, through an autocrine pathway, promotes meiotic entry and progression of spermatogonia, as revealed by the meiotic organization of nuclear SCP3 (green) during the prophase I phases (leptotene, zygotene, pachytene). 


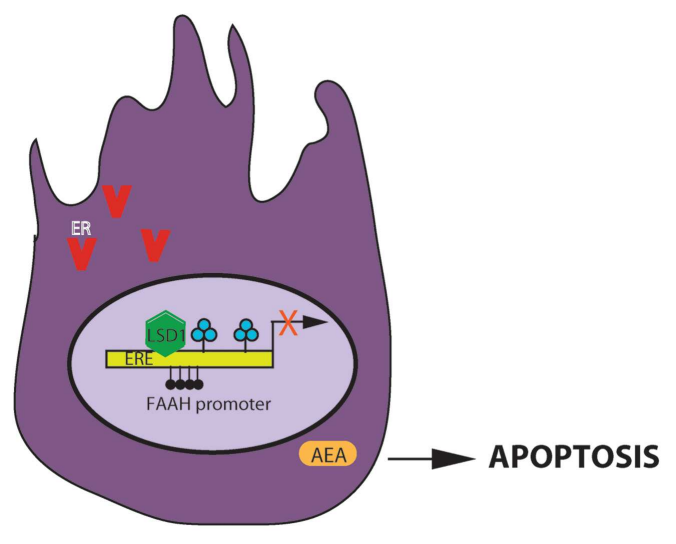

FIGURE 2 | Regulation of AEA-degrading enzyme FAAH expression by estrogen in Sertoli cells. $E_{2}$ regulates FAAH transcription by direct binding of estrogen receptor (ER) and epigenetic mechanisms including histone modification and DNA methylation. On the left: in the absence of estrogens, faah proximal promoter is methylated at DNA CpG sites and at lysine 9 of $\mathrm{H} 3$ histone and it is not competent for transcription. The final outcome is an increase AEA-induced apoptosis of Sertoli cells. On

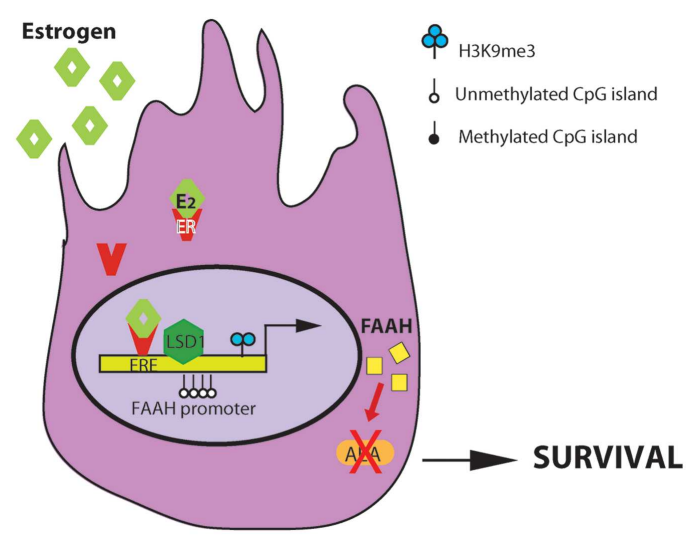

the right: estrogens activates the AEA-degrading enzyme FAAH transcription, through ER binding at ERE sites and reduction of DNA and $\mathrm{H} 3 \mathrm{~K} 9 \mathrm{me} 3$ methylation. The direct/indirect interaction with histone demethylase LSD1, constitutively recruited at this site, is necessary for estrogen-induced transcription. The final outcome is a decrease of AEA-induced apoptosis of Sertoli cells (ERE, estrogen response element). presence of estrogens in male reproductive tracts of numerous mammals has been reported (52). Aromatase is the enzyme that converts irreversibly androgen into estrogens and is expressed, in mammals, in all testicular cells except peritubular cells. The biological effects of estrogens are mediated by the estrogen receptors $\alpha$ $(\mathrm{ER} \alpha)$ and $\beta(\mathrm{ER} \beta)$, both expressed in mammalian testis. A role of estrogens in spermatogenesis is strongly supported by the observation that mice lacking estrogen receptors or aromatase are infertile and show impaired spermatogenesis in adulthood $(53,54)$.

Between all the components of ECS, the AEA-degrading enzyme faah gene has been demonstrated to be the only gene to be hormonally regulated in the testis. In Sertoli cells, FSH regulates FAAH expression and activity by triggering protein kinase A or aromatase-dependent pathway (42).

The PKA-dependent pathway enhances FAAH activity by inducing phosphorylation of other proteins that could activate the enzyme. On the other hand, the aromatase-dependent pathway, that leads to the conversion of testosterone into estrogens, induces FAAH expression at transcriptional level. Indeed we recently clarify the molecular mechanisms by which estrogens directly upregulate faah gene transcription (55). This involves direct binding of ER to the ERE sites in the faah promoter and the induction of epigenetic modifications in order to confer transcriptional competence.

As presented in Figure 2, in Sertoli cells, $\mathrm{E}_{2}$ engages ER, which binds to ERE sites in the faah proximal promoter determining demethylation of both DNA, at CpG site, and histone $\mathrm{H} 3$, at lysine 9 (H3K9). The presence of histone demethylase LSD1, which is recruited at this site, ensures estrogens stimulation of faah transcription. LSD1 could interact with ligand-bound ER or with other different partners and activate gene transcription. The biological relevance of $\mathrm{E}_{2}$-stimulation of $\mathrm{FAAH}$ expression consists in decreasing AEA levels in Sertoli cells and protect them against apoptosis induced by AEA. The pro-survival role of $E_{2}$ in Sertoli cells has a clear impact on spermatogenesis. In fact regulation of Sertoli cell apoptosis could be important to maintain their population size, and consequently, to sustain a normal spermatogenic output.

This is not the only example about the cross-talks between estrogens and ECS in the testis. Recent evidences reveal that estrogens affect spermiogenesis and regulate chromatin remodeling of germ cells (56). Indeed, in mice, genetic loss of $\mathrm{CB}_{1}$ receptor causes a reduction in FSH and estrogen plasma levels and alteration in spermatid differentiation due to an inefficient histone displacement in the sperm. Estrogens treatment is able to rescue histone displacement suggesting a role in preserving chromatin condensation in spermatozoa.

\section{CONCLUDING REMARIKS}

In this mini-review we highlighted the physiological role of ECS and its interplay with sex hormones, in male reproduction. A full comprehension of the molecular events regulated by ECS in the testis will allow to better define the "protective" role of this system in maintaining and ensuring the correct progression of spermatogenesis and the formation of mature and fertilizing sperm. Interfering with this system by exposure to exogenous cannabinoids, may alter the physiological function of ECS in male reproduction thus affecting male fertility.

\section{ACKNOWLEDGMENTS}

This work was supported by grants from Agenzia Spaziale Italiana.

\section{REFERENCES}

1. Daling JR, Doody DR, Sun X, Trabert BL, Weiss NS, Chen C, et al. Association of marijuana use and the incidence of testicular germ cell tumors. Cancer (2009) 115(6):1215-23. doi:10.1002/cncr.24159

2. de Rooij DG. Proliferation and differentiation of spermatogonial stem cells. Reproduction (2001) 121:347-54. doi:10.1530/rep.0.1210347

3. Orth JM, Gunsalus GI, Lamperti AA. Evidence from Sertoli cell-depleted rats indicates that spermatid number in adults depends on numbers of Sertoli cells 
produced during perinatal development. Endocrinology (1988) 122(3):787-94. doi:10.1210/endo-122-3-787

4. Meng X, Lindahl M, Hyvonen ME, Parvinen M, De Rooij DG, Hess MW, et al. Regulation of cell fate decision of undifferentiated spermatogonia by GDNF. Science (2000) 287:1489-93. doi:10.1126/science.287.5457.1489

5. Pellegrini M, Grimaldi P, Rossi P, Geremia R, Dolci S. Developmental expression of BMP4/ALK3/SMAD5 signaling pathway in the mouse testis: a potential role of BMP4 in spermatogonia differentiation. J Cell Sci (2003) 116:3363-72. doi: $10.1242 /$ jcs.00650

6. Rossi P, Dolci S, Albanesi C, Grimaldi P, Ricca R, Geremia R. Follicle-stimulating hormone induction of steel factor (SLF) mRNA in mouse Sertoli cells and stimulation of DNA synthesis in spermatogonia by soluble SLF. Dev Biol (1993) 155:68-74. doi:10.1006/dbio.1993.1007

7. Dolci S, Pellegrini M, Di Agostino S, Geremia R, Rossi P. Signaling through extracellular signal-regulated kinase is required for spermatogonial proliferative response to stem cell factor. J Biol Chem (2001) 276:40225-33.

8. Matzuk MM, Lamb DJ. The biology of infertility: research advances and clinical challenges. Nat Med (2008) 14(11):1197-213. doi:10.1038/nm.f.1895

9. Di Marzo V, Melck D, Bisogno T, De Petrocellis L. Endocannabinoids: endogenous cannabinoid receptor ligands with neuromodulatory action. Trends Neurosci (1998) 21:521-8. doi:10.1016/S0166-2236(98)01283-1

10. Howlett AC, Barth F, Bonner TI, Cabral G, Casellas P, Devane WA, et al. International Union of Pharmacology. XXVII. Classification of cannabinoid receptors. Pharmacol Rev (2002) 54(2):161-202. doi:10.1124/pr.54.2.161

11. Van Sickle MD, Duncan M, Kingsley PJ, Mouihate A, Urbani P, Mackie K, et al. Identification and functional characterization of brainstem cannabinoid $\mathrm{CB}_{2}$ receptors. Science (2005) 310:329-32.

12. Okamoto Y, Morishita J, Tsuboi K, Tonai T, Ueda N. Molecular characterization of a phospholipase D generating anandamide and its congeners. J Biol Chem (2004) 279:5298-305. doi:10.1074/jbc.M306642200

13. Bisogno T, Howell F, Williams G, Minassi A, Cascio MG, Ligresti A, et al. Cloning of the first sn1-DAG lipases points to the spatial and temporal regulation of endocannabinoid signaling in the brain. J Cell Biol (2003) 163(3):463-8. doi:10.1083/jcb.200305129

14. Beltramo M, Stella N, Calignano A, Lin SY, Makriyannis A, Piomelli D. Functional role of high-affinity anandamide transport, as revealed by selective inhibition. Science (1997) 277(5329):1094-7. doi:10.1126/science.277.5329.1094

15. Beltramo M, Piomelli D. Carrier-mediated transport and enzymatic hydrolysis of the endogenous cannabinoid 2-arachidonylglycerol. Neuroreport (2000) 11(6):1231-5. doi:10.1097/00001756-200004270-00018

16. Fu J, Bottegoni G, Sasso O, Bertorelli R, Rocchia W, Masetti M, et al. A catalytically silent FAAH-1 variant drives anandamide transport in neurons. Nat Neurosci (2011) 15(1):64-9. doi:10.1038/nn.2986

17. McKinney MK, Cravatt BF. Structure and function of fatty acid amide hydrolase. Annu Rev Biochem (2005) 74:411-32. doi:10.1146/annurev.biochem.74.082803. 133450

18. Dinh TP, Carpenter D, Leslie FM, Freund TF, Katona I, Sensi SL, et al. Brain monoglyceride lipase participating in endocannabinoid inactivation. Proc Natl Acad Sci U S A (2002) 99:10819-24. doi:10.1073/pnas.152334899

19. Di Marzo V, De Petrocellis L. Endocannabinoids as regulators of transient receptor potential (TRP) channels: a further opportunity to develop new endocannabinoid-based therapeutic drugs. Curr Med Chem (2010) 17:1430-49. doi:10.2174/092986710790980078

20. Caterina MJ, Schumacher MA, Tominaga M, Rosen TA, Levine JD, Julius D. The capsaicin receptor: a heat-activated ion channel in the pain pathway. Nature (1997) 389:816-24. doi:10.1038/39807

21. Wang H, Dey SK, Maccarrone M. Jekyll and hyde: two faces of cannabinoid signaling in male and female fertility. Endocr Rev (2006) 27(5):427-48. doi:10.1210/er.2006-0006

22. Schuel H, Schuel R, Zimmerman AM, Zimmerman S. Cannabinoids reduce fertility of sea urchin sperm. Biochem Cell Biol (1987) 65(2):130-6. doi:10.1139/ 087-018

23. Schuel H, Berkery D, Schuel R, Chang MC, Zimmerman AM, Zimmerman S. Reduction of the fertilizing capacity of sea urchin sperm by cannabinoids derived from marihuana. I. Inhibition of the acrosome reaction induced by egg jelly. Mol Reprod Dev (1991) 29(1):51-9. doi:10.1002/mrd.1080290109

24. Schuel H, Goldstein E, Mechoulam R, Zimmerman AM, Zimmerman S. Anandamide (arachidonylethanolamide), a brain cannabinoid receptor agonist, reduces sperm fertilizing capacity in sea urchins by inhibiting the acrosome reaction. Proc Natl Acad Sci U S A (1994) 91(16):7678-82. doi:10.1073/pnas.91. 16.7678

25. Schuel H, Burkman LJ, Lippes J, Crickard K, Forester E, Piomelli D, et al. Nacylethanolamines in human reproductive fluids. Chem Phys Lipids (2002) 121:211-27. doi:10.1016/S0009-3084(02)00158-5

26. Cobellis G, Cacciola G, Scarpa D, Meccariello R, Chianese R, Franzoni MF, et al. Endocannabinoid system in frog and rodent testis: type- 1 cannabinoid receptor and fatty acid amide hydrolase activity in male germ cells. Biol Reprod (2006) 75(82):89. doi:10.1095/biolreprod.106.051730

27. Cobellis G, Ricci G, Cacciola G, Orlando P, Petrosino S, Cascio MG, et al. A gradient of 2-arachidonoylglycerol regulates mouse epididymal sperm cell start-up. Biol Reprod (2010) 82(2):451-8. doi:10.1095/biolreprod.109.079210

28. Rossato M, Popa FI, Ferigo M, Clari G, Foresta C. Human sperm express cannabinoid receptor CNR1, the activation of which inhibits motility, acrosome reaction and mitochondrial function. J Clin Endocrinol Metab (2005) 90:984-91.

29. Maccarrone M, Barboni B, Paradisi A, Bernabò N, Gasperi V, Pistilli MG, et al. Characterization of the endocannabinoid system in boar spermatozoa and implications for sperm capacitation and acrosome reaction. J Cell Sci (2005) 118:4393-404. doi:10.1242/jcs.02536

30. Chioccarelli T, Cacciola G, Altucci L, Lewis SE, Simon L, Ricci G, et al. Cannabinoid receptor 1 influences chromatin remodeling in mouse spermatids by affecting content of transition protein $2 \mathrm{mRNA}$ and histone displacement. Endocrinology (2010) 151(10):5017-29. doi:10.1210/en.2010-0133

31. Ricci G, Cacciola G, Altucci L, Meccariello R, Pierantoni R, Fasano S, et al. Endocannabinoid control of sperm motility: the role of epididymus. Gen Comp Endocrinol (2007) 153(1-3):320-2. doi:10.1016/j.ygcen.2007.02.003

32. Sun X, Wang H, Okabe M, Mackie K, Kingsley PJ, Marnett LJ, et al. Genetic loss of Faah compromises male fertility in mice. Biol Reprod (2009) 80(2):235-42. doi:10.1095/biolreprod.108.072736

33. Lewis SE, Paro R, Borriello L, Simon L, Robinson L, Dincer Z, et al. Long-term use of HU210 adversely affects spermatogenesis in rats by modulating the endocannabinoid system. Int J Androl (2012) 35(5):731-40. doi:10.1111/j.1365-2605. 2012.01259.x

34. De Petrocellis L, Bisogno T, Maccarrone M, Davis JB, Finazzi-Agro A, Di Marzo $\mathrm{V}$. The activity of anandamide at vanilloid VR1 receptors requires facilitated transport across the cell membrane and is limited by intracellular metabolism. J Biol Chem (2001) 276:12856-63. doi:10.1074/jbc.M008555200

35. Grimaldi P, Orlando P, Di Siena S, Lolicato F, Petrosino S, Bisogno T, et al. The endocannabinoid system and pivotal role of the $\mathrm{CB}_{2}$ receptor in mouse spermatogenesis. Proc Natl Acad Sci U S A (2009) 106(27):11131-6. doi:10.1073/ pnas.0812789106

36. Gervasi MG, Osycka-Salut C, Caballero J, Vazquez-Levin M, Pereyra E, Billi S, et al. Anandamide capacitates bull spermatozoa through CB1 and TRPV1 activation. PLoS One (2011) 6(2):e16993. doi:10.1371/journal.pone.0016993

37. Francavilla F, Battista N, Barbonetti A, Vassallo MR, Rapino C, Antonangelo C, et al. Characterization of the endocannabinoid system in human spermatozoa and involvement of transient receptor potential vanilloid 1 receptor in their fertilizing ability. Endocrinology (2009) 150(10):4692-700. doi:10.1210/en.20090057

38. Wang H, Xie H, Guo Y, Zhang H, Takahashi T, Kingsley PJ, et al. Fatty acid amide hydrolase deficiency limits early pregnancy events. J Clin Invest (2006) 116(8):2122-31. doi:10.1172/JCI28621

39. Catanzaro G, Battista N, Rossi G, Di Tommaso M, Pucci M, Pirazzi V, et al. Effect of capacitation on the endocannabinoid system of mouse sperm. Mol Cell Endocrinol (2011) 343(1-2):88-92. doi:10.1016/j.mce.2011.01.022

40. Lewis SE, Rapino C, Di Tommaso M, Pucci M, Battista N, Paro R, et al. Differences in the endocannabinoid system of sperm from fertile and infertile men. PLoS One (2012) 7(10):e47704. doi:10.1371/journal.pone.0047704

41. Amoako AA, Marczylo TH, Marczylo EL, Elson J, Willets JM, Taylor AH, et al. Anandamide modulates human sperm motility: implications for men with asthenozoospermia and oligoasthenoteratozoospermia. Hum Reprod (2013) 28(8):2058-66. doi:10.1093/humrep/det232

42. Maccarrone M, Cecconi S, Rossi G, Battista N, Pauselli R, Finazzi-Agro A. Anandamide activity and degradation are regulated by early postnatal aging and follicle-stimulating hormone in mouse Sertoli cells. Endocrinology (2003) 144:20-8. doi:10.1210/en.2002-220544 
43. Rossi G, Gasperi V, Paro R, Barsacchi D, Cecconi S, Maccarrone M. Folliclestimulating hormone activates fatty acid amide hydrolase by protein kinase A and aromatase-dependent pathways in mouse primary Sertoli cells. Endocrinology (2007) 148:1431-9. doi:10.1210/en.2006-0969

44. Grimaldi P, Rossi G, Catanzaro G, Maccarrone M. Modulation of the endocannabinoid-degrading enzyme fatty acid amide hydrolase by folliclestimulating hormone. Vitam Horm (2009) 81:231-61. doi:10.1016/S00836729(09)81010-8

45. Cacciola G, Chioccarelli T, Mackie K, Meccariello R, Ledent C, Fasano S, et al. Expression of type-1 cannabinoid receptor during rat postnatal testicular development: possible involvement in adult Leydig cell differentiation. Biol Reprod (2008) 79(4):758-65. doi:10.1095/biolreprod.108.070128

46. Symons AM, Teale JD, Marks V. Effect of delta-9-tetrahydrocannabinol on the hypothalamic-pituitary-gonadal system in the maturing male rat. Endocrinology (1976) 68:43-4.

47. Dalterio S, Bartke A, Burstein S. Cannabinoids inhibit testosterone secretion by mouse testes in vitro. Science (1977) 196:1472-3. doi:10.1126/science.867048

48. Gorzalka BB, Hill MN, Chang SC. Male-female differences in the effects of cannabinoids on sexual behavior and gonadal hormone function. Horm Behav (2010) 58(1):91-9. doi:10.1016/j.yhbeh.2009.08.009

49. Jakubovic A, McGeer E, McGeer P. Effects of cannabinoids on testosterone and protein synthesis in rat testis Leydig cells in vitro. Mol Cell Endocrinol (1979) 15:41-50. doi:10.1016/0303-7207(79)90069-8

50. Wenger T, Ledent C, Csernus V, Gerendai I. The central cannabinoid receptor inactivation suppresses endocrine reproductive functions. Biochem Biophys Res Commun (2001) 284:363-8. doi:10.1006/bbrc.2001.4977

51. O’Donnell L, Robertson K-M, Jones M-E, Simpson E-R. Estrogen and spermatogenesis. Endocr Rev (2001) 22:289-318. doi:10.1210/er.22.3.289

52. Hess RA. Estrogen in the adult male reproductive tract: a review. Reprod Biol Endocrinol (2003) 1:52. doi:10.1186/1477-7827-1-52

53. Eddy E-M, Washburn TF, Bunch DO, Goulding EH, Gladen BC, Lubahn $\mathrm{DB}$, et al. Targeted disruption of the estrogen receptor gene in male mice causes alteration of spermatogenesis and infertility. Endocrinology (1996) 137:4796-805. doi:10.1210/en.137.11.4796

54. Robertson KM, O'Donnell L, Jones ME, Meachem SJ, Boon WC, Fisher $\mathrm{CR}$, et al. Impairment of spermatogenesis in mice lacking a functional aromatase (cyp 19) gene. Proc Natl Acad Sci U S A (1999) 96:7986-91. doi:10.1073/pnas. 96.14.7986

55. Grimaldi P, Pucci M, Di Siena S, Di Giacomo D, Pirazzi V, Geremia R, et al. The faah gene is the first direct target of estrogen in the testis: role of histone demethylase LSD1. Cell Mol Life Sci (2012) 69(24):4177-90. doi:10.1007/ s00018-012-1074-6

56. Cacciola G, Chioccarelli T, Altucci L, Ledent C, Mason JI, Fasano S, et al. Low 17beta-estradiol levels in CNR1 knock-out mice affect spermatid chromatin remodeling by interfering with chromatin reorganization. Biol Reprod (2013) 88(6):152. doi:10.1095/biolreprod.112.105726

Conflict of Interest Statement: The authors declare that the research was conducted in the absence of any commercial or financial relationships that could be construed as a potential conflict of interest.

Received: 04 November 2013; paper pending published: 17 November 2013; accepted: 29 November 2013; published online: 16 December 2013.

Citation: Grimaldi P, Di Giacomo D and Geremia R (2013) The endocannabinoid system and spermatogenesis. Front. Endocrinol. 4:192. doi: 10.3389/fendo.2013.00192 This article was submitted to Experimental Endocrinology, a section of the journal Frontiers in Endocrinology.

Copyright (c) 2013 Grimaldi, Di Giacomo and Geremia. This is an open-access article distributed under the terms of the Creative Commons Attribution License (CC BY). The use, distribution or reproduction in other forums is permitted, provided the original author(s) or licensor are credited and that the original publication in this journal is cited, in accordance with accepted academic practice. No use, distribution or reproduction is permitted which does not comply with these terms. 